\title{
The Potency of Semax Peptide Therapy toward MDA Level and Protein Profile in Epilepsy Rats (Rattus norvegicus)
}

\author{
Ratna Puspita ${ }^{1 a^{*}}$, Dian Pratamastuti ${ }^{2}$, Anna Safitri ${ }^{1,}$ and Aulanni'am Aulanni'am ${ }^{1,3, *}$ \\ ${ }^{1}$ Department of Chemistry, Faculty of Sciences, Brawijaya University, Malang. \\ Neuro developmental Study Group of Airlangga University, Surabaya. \\ ${ }^{3}$ Faculty of Veterinary Medicine, Brawijaya University, Malang.
}

${ }^{\text {a)} C o r r e s p o n d i n g ~ a u t h o r: ~ r a t n a p u s p i t a 97 @ y a h o o . c o . i d ~ b) a u l a n i @ u b . a c . i d ~}$

\begin{abstract}
Epilepsy is a disruption of brain function that is characterized by abnormal depolarization of neurons. One signs of epilepsy is seizures, which caused by brain injury. Epilepsy can cause morbidity and mortality, thus, many drugs are used to treat epilepsy. But these drugs have negative health effects. This research was using semax peptide as alternative therapy, because it is a neuropeptide that directly acts on the central nervous system and free from hormonal activity, therefore it will not cause negative health effects. Moreover, semax peptide is an antioxidant and can synthesize some proteins in brain. The potency of semax peptide therapy on epilepsy rats can be analyzed by MDA level and proteins profiles on the brain. The epilepsy rats were prepared by using $\mathrm{LiCl}$ and pilocarpine induction. Then rats were treated with $50 \mu \mathrm{g} / \mathrm{kg}$ body weight of semax peptide. Analysis of MDA level was measured using TBA test while protein profiles were determined using SDS-PAGE method. The result showed that semax peptide reduced MDA levels up to $40.46 \%$ and synthesize 3 kinds of proteins that were not synthesized on epilepsy rats. Those proteins have molecular weights of $93.54 \mathrm{kDa}, 66.76 \mathrm{kDa}$, and $59.66 \mathrm{kDa}$. In conclusion, $50 \mu \mathrm{g} / \mathrm{kg}$ body weight dose of semax peptide can be used for the treatment of epilepsy.
\end{abstract}

Keywords: epilepsy, semax peptide, malondyaldehyde, protein profile

\section{INTRODUCTION}

Epilepsy is a disruption of brain function that is characterized by abnormal depolarization of neurons. One a sign of epilepsy is seizures [1]. Seizures can also be caused by conduction abnormalities potassium ion channel defect and deficiency ATPase associated with ion transport, thus causing the brain cell membrane fluidity. Brain cell membranes under normal condition easily traversed by potassium ions and chloride ions, but it is very difficult to pass by sodium ions and calcium ions [2, 3]. Brain cell damage can be caused abnormal brain cell metabolism. Brain has oxidative stress and produce MDA. MDA levels can indicate the number of free radicals in brain, so it can be analysis in epilepsy brain condition [4, 5]. Moreover protein is a very heterogeneous biomacromolecules, almost all macromolecules in the body composed of protein especially in brain. It is very unstable molecule which is sensitive to denaturized or protein structure changes by protein reactions with chemical compounds [6], so proteins profile can be analysis in epilepsy brain condition. Epilepsy can cause morbidity and mortality, so many drugs used to treat epilepsy. But these drugs have negative health effects. Those can cause hypersensitivity of brain and interfere with directly brain function [7].

Semax peptide or ACTH (4-10) is a short fragment or analog of ACTH (adrenocorticotropic hormone). Semax is heptapeptida that composed of methionine-glutamic acid-histidinefenilalanine-proline-glycine-proline amino acids. Semax peptide is neuron medicine. It was tested through human clinical trials that free from health negative effects and hormonal activity, because 
it can directly react with CNS. It benefits in protecting brain cells, so that it can optimize the metabolic processes of the brain cells and improve cognitive function. It is an antioxidant and can synthesize some proteins in brain [8-10]. Due to these reasons, in this research semax peptide was used as an alternative therapy, in order to study the potency of it in reducing MDA levels and improvement of proteins profiles on brain of epilepsy rats.

\section{METHODS}

The epilepsy rats were prepared by using $\mathrm{LiCl}$ and pilocarpine inductions. Then rats were treated with $50 \mu \mathrm{g} / \mathrm{kg}$ of body weight dose semax peptide. The rats were divided into three groups: group $\mathrm{A}$ is a negative control (health rats), group B is a positive control (inducted by $254.4 \mathrm{mg} / \mathrm{kg}$ dose of $\mathrm{LiCl}+60 \mathrm{mg} / \mathrm{kg}$ dose of pilocarpine $+0.3 \mathrm{mg} / \mathrm{kg}$ of diazepam + placebo), and group $\mathrm{C}$ was therapy (inducted by $254.4 \mathrm{mg} / \mathrm{kg}$ dose of $\mathrm{LiCl}+60 \mathrm{mg} / \mathrm{kg}$ dose of pilocarpine $+0.3 \mathrm{mg} / \mathrm{kg}$ of diazepam $+50 \mu \mathrm{g} / \mathrm{kg} \mathrm{BW}$ dose semax peptide). The number of rats each group consisting of 8 rats. Train surgery rats were conducted by necropsy. The MDA level were measured by TBA test [4], and protein profile were confirmed by SDS-PAGE method [6].

\section{RESULTS AND DISCUSSION}

\subsection{Epilepsy rats}

The epilepsy rats were prepared by using $\mathrm{LiCl}$ and pilocarpine inductions. Epilepsy condition in this research

confirmed by epilepticus 4th stadium. Epilepticus 4th stadium in rats when the tail of rat has stiff [7].

\subsection{MDA Levels}

The results showed that $\mathrm{LiCl}$ and pilocarpine induction increased oxidative stress in brain cells, with elevated

MDA levels percentage from $86.31 \%$ of $0.43 \pm 0.011 \mu \mathrm{g} / \mathrm{mL}$ to $3.11 \pm 0.028 \mu \mathrm{g} / \mathrm{mL}$. After semax peptide treatment, the MDA levels reduced up to $40.46 \%$ to $1.85 \pm 0.020 \mu \mathrm{g} / \mathrm{mL}$ (Figure 1 ).

$\mathrm{LiCl}$ was ionized and metabolized by lipooxygenase enzyme in brain cells. The metabolism produces hypochlorite acid $(\mathrm{HOCl})$ reactive. Lipooxygenase enzyme found in many tissues of the brain that acts as an oxidant. The enzyme utilizes hydrogen peroxide $\left(\mathrm{H}_{2} \mathrm{O}_{2}\right)$ to oxidize chloride ion $\left(\mathrm{Cl}^{-}\right)$into ROS. $\mathrm{HOCl}$ binds with oxygen to produce chlorine monoxide $(\mathrm{ClO})$, which is more reactive. The formation of radicals has continued through a chain of reactions called lipid peroxidation, forming new radicals that are highly reactive. It brings damage to the brain tissues, because radicals are compounds that have unpaired electron and are highly unstable makes it is very reactive. As a result, radicals in the brain cells attack the polyunsaturated fatty acids (PUFA) which apart from lipid membrane bilayer in order to achieve stability. Radical lipid accepts hydrogen atoms of PUFA forming lipid hydro peroxide. Furthermore, hyper peroxide lipid releases other lipid radicals to form MDA. The process will continue until a stable compound formed by antioxidants [11-13]. 


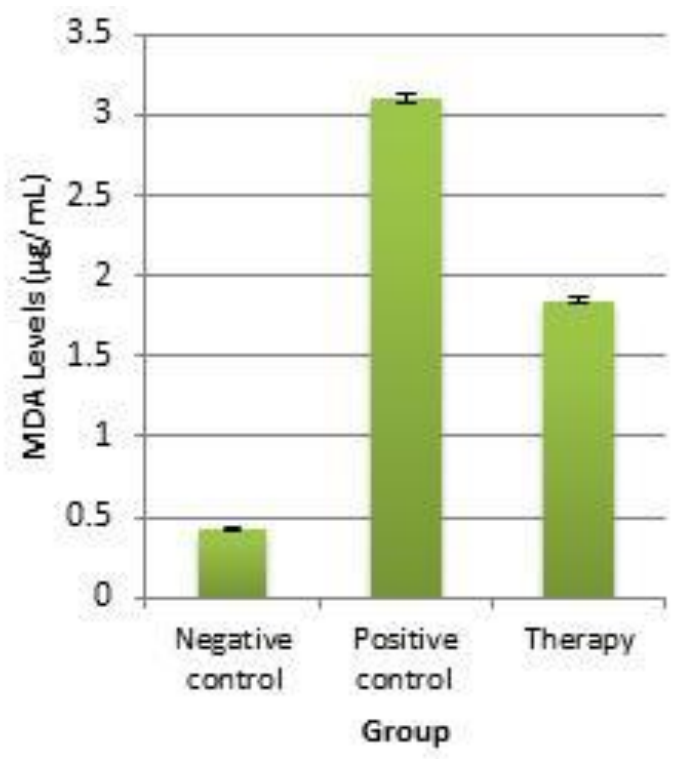

FIGURE 1. MDA Levels in Brain Rats

Details: Group A is negative control; group B is positive control; and group C is semax peptide therapy.

Semax peptide induced the transformation of metabolic chain that significantly lowers inflammatory factors and increasing anti-inflammatory. These reactions can reduce lipid peroxidation [14]. Semax peptides act as an antioxidant, because it can inhibit the formation of free radicals, preventing or inhibiting lipid peroxidation. The hydroxyl group $(\mathrm{OH})$ at semax peptide act as antioxidants. The mechanism of inhibition of free radicals by semax peptide by quickly covering the hydroxyl group $(\mathrm{OH})$ donate hydrogen atom to the lipid radicals. Semax peptides suppress the activity of the enzyme lipooxygenase, thereby suppress oxidative damage.. Semax radicals generated relatively stable than lipid radicals. As a result, radicals semax do not have enough energy to react with other lipid molecules that do not form new lipid radicals. Therefore, semax peptide can reduce the production of MDA.

\subsection{Profile of Proteins}

Semax peptide therapy in epilepsy rats caused changes in brain protein profile. Based on brain protein profiles that confirmed by SDS-PAGE method (Figure 2), group A showed the protein profiles with a specific molecular mass. Then in group B three proteins did not express and expressed a new protein. Group $\mathrm{C}$ showed that semax peptide synthesize three kinds of proteins were not synthesized before on epilepsy rats. 


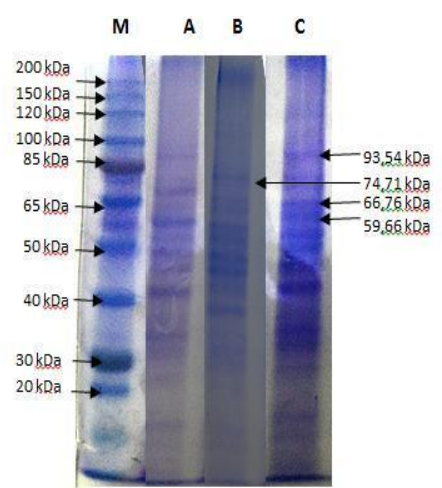

FIGURE 2. Brain Protein Profiles Rats from SDS-PAGE results

Details: $\mathrm{M}$ is marker; A is Group A (negative control); B is group B (positive control); and C is group $\mathrm{C}$ (semax peptide therapy).

Proteins did not express in group B were: 1) a $93.54 \mathrm{kDa}$ protein, alpha-globulin group [15]; 2) a $66.76 \mathrm{kDa}$ albumin group [16]; and 3) a59.66 kDa protein, group of glutamic dehydrogenase [17]. There is a new protein with a molecular mass of $74.71 \mathrm{kDa}$ that is a heat shock protein (Hsp70) [18]. Semax peptide therapy (Group C), improve protein profiles compared with epilepsy rats (Group B). In group C (group therapy semax) produces the brain protein profiles resembles the protein profiles in group A (negative control group). However semax peptide therapy dose of $50 \mu \mathrm{g} / \mathrm{kg}$ BW still synthesis of Hsp 70. The result proved that semax peptide therapy with dose of $50 \mu \mathrm{g} / \mathrm{kg}$ BW on the synthesis of Hsp70 has not been optimum. Hsp70 is a protein synthesized by brain cells and glia. It is synthesized in normal condition to stabilize the protein brain cells. It is as anti-aphotic. It acts as a natural defence of cells against free radicals. Free radicals can damage proteins bind to the protein due to the fragmentation so as to accelerate the process of proteolysis [19, 20].Semax peptide is neuropeptide or protein in neurons. Its function as a neurotransmitter, which can penetrate the blood-brain barrier and directly enter into brain cells. It provides metabolic regulation, neuroprotection, neuromodulation and neurotrophic activity [21].

\section{CONCLUSION}

This study provides evidence that semax peptide therapy on epilepsy rats decrease MDA level and improve protein profiles in the brain of epilepsy.

\section{Acknowledgement}

This study was supported by Biochemistry Laboratory and Institute Bioscience Brawijaya University, for providing the facilities in research.

\section{References}

1. Damudoro N., Epilepsi Anak dan Kejang Demam, Simposium Penatalaksanaan Mutakhir Epilepsi (FK UGM, Yogyakarta, 1992).

2. Yunus, Moch, Pengaruh Antioksidan Vitamin C Terhadap MDA Eritrosit Tikus Wistar Akibat Latihan Anaerobik, Jurnal Pendidikan Jasmani, (1) 2001: 9-16.

3. Chandra B., Patofisiologi Epilepsi dalam Epilepsi (BP UNDIP, Semarang, 1993).

4. Asni, E., dkk., Pengaruh Hipoksia Berkelanjutan Terhadap Kadar Malondialdehid, Glutation Tereduksi, dan Aktivitas Katalase Ginjal Tikus, Maj. Kedokt. Indones., 59(12) 2009: 595-600.

5. Swastika, 2013. MDA)“KadarpadaAbortus Inkomplit Lebih Tinggi Dibandingkan dengan Kehamilan Normal,'Program Studi Ilmu Tesis Biomedik,Universitas Udaya.

6. Fatchiyah,Arumingtyas, E.L., Widyarti, S., Rahayu, S., Biologi Molekuler-Prinsip Dasar 
Analisis (Erlangga, Jakarta, 2011).

7. Panayiotopoulos CP., The epilepsies seizures, syndromes and management (Blandon Medical Publishing, Oxfordshire, 2005).

8. Manchenko D., Vilensky D., Levitskaya N., Kamensky A., Myasoedov N., Considerably Different Mechanisms

Underlie The Effects of The ACTH(4-Induced-10)AnalgesiaAnalogueandStress$S$

Induced Behavior, Federal Targeted Program-educational

"Scientificpersonnelofinnovative and

Russia, 2009: (P1057).

9. Roxane, Diazepam Oral Solution $5 \mathrm{mg}$ per $5 \mathrm{~mL}$ Diazepam Intensol ${ }^{T M}$ Oral Solution $^{2}$ (Concentrate) $5 \mathrm{mg}$ per $\mathrm{mL}$

(Roxane Laboratories, Inc, Columbus, Ohio 43216, 2012).

10. Eremin KO, Kudrin VS, Grivennikov IA, Miasoedov NF, Rayevsky KS., Effects Of Semax Peptide on Dopaminergic and Serotoninergic Systems of The Brain, Dokl Biol Sci;394, 2004: 1-3.

11. Carr Chloe, An Investigation of The Effects of LiCl and The -RoleCateninin LumbriculusOfB Variegatus Patterning (developmental Biology, 2005).

12. Marnett, L.J., Lipid Peroxidation DNA Damage by Malondyaldehyde, Mutation Research (1999): 424, 8-95.

13. Aral, H. And A. Vecchio-Sadus, Toxicity Of Lithium To Humans and The EnvironmentA Literature Review, Ecotoxicology and Environmental Safety 70 (2008): 349-356.

14. Gusev, E.I; Skvortsova, Brain Ischemia. Kluwer Academic/ Plenum Publishers, New York (2003): 297-323.

15. Keren, David F., Protein Electrophoresis in Clinical Diagnosis, Holder Arnold (2003), pp. 1-14, ISBN 0340812133.

16. Lehninger A, Nelson D, Cox M M., Principles of Biochemistry $2^{\text {nd }}$ (1993): 710-711.

17. Reeds, P.J., et al., Intestinal Glutamate Metabolism, Journal of Nutrition, 130(4s) (2000): 978S-982S.

18. Murray R K, et al., Harper's Biochemistryed.Appleton\&Lange.America25 (2000): 359373.

19. S Theresia Indah Budhy, Istiati K, Soehardjo, Peran Heat Shock Protein (HSP) terhadap Penyakit Rongga Mulut

(Bagian Biologi Oral, Fakultas Kedokteran GIgi universitas Airlangga, 2006).

20. Nollen and Richrd, Heat Shock Protein, J Set (2002); 2809.

21. Semax International Inc., Semax, www.semaxint.com (2003-2008), (7 September 2016). 